\title{
Conjunctival swab PCR to detect Leishmania spp. in cats
}

\author{
Uso da PCR de suabe conjuntival para detecção de Leishmania spp. em gatos \\ Trícia Maria Ferreira de Sousa Oliveira ${ }^{1,2^{*}}$; Vanessa Figueredo Pereira ${ }^{2}$; Graziella Ulbricht Benvenga ${ }^{2}$; \\ Maria Fernanda Alves Martin ${ }^{3}$; Julia Cristina Benassi ${ }^{1}$; Diogo Tiago da Silva ${ }^{3}$; Wilma Aparecida Starke-Buzetti ${ }^{3}$ \\ ${ }^{1}$ Departamento de Medicina Veterinária, Faculdade de Zootecnia e Engenharia de Alimentos, Universidade de São Paulo - USP, \\ Pirassununga, SP, Brazil \\ ${ }^{2}$ Programa de Pós-Graduação em Epidemiologia Experimental Aplicada às Zoonoses, Faculdade de Medicina Veterinária e Zootecnia, \\ Universidade de São Paulo - USP, São Paulo, SP, Brazil \\ ${ }^{3}$ Departamento de Biologia e Zootecnia, Faculdade de Engenharia, Universidade Estadual Paulista - UNESP, Ilha Solteira, SP, Brazil
}

Received October 30, 2014

Accepted February 4, 2015

\begin{abstract}
The relevance of the dog as a source of visceral leishmaniasis infection is known, but the role of cats as reservoir hosts for leishmaniasis is not yet fully clear. This study assessed the efficacy of conjunctival swab PCR (CS-PCR) in the detection of cats infected by Leishmania spp. The results were seven (13.5\%) cats positive for Leishmania spp. in the PCR, in 52 cats tested from Pirassunuga-SP and Ilha Solteira-SP. From the city of Pirassununga - SP 28.6\% (2/7) were positive and from the city of Ilha Solteira - SP 11.1\% (5/45) were positive. The results showed that CS-PCR was capable of detecting cats infected by this protozoan. Conjunctival swab samples proved easier to perform in cats, which might facilitate studies on the frequency and distribution of feline leishmaniasis.
\end{abstract}

Keywords: Conjunctival swab, PCR, cats.

\section{Resumo}

A importância do cão como fonte de infecção da leishmaniose visceral já é conhecida, mas o papel dos gatos como reservatórios das leishmanioses ainda não está totalmente esclarecido. O presente estudo avaliou a eficácia da PCR de suabe conjuntival (PCR-SC) na detecção de gatos infectados por Leishmania spp. Foram encontrados sete (13,5\%) gatos positivos para Leishmania spp. na PCR de suabe conjuntival, dentre 52 animais de Pirassununga - SP e Ilha Solteira - SP testados. Sendo positivos 28,6\% (02/07) dos gatos do município de Pirassununga e 11,1\% (5/45) dos gatos do município de Ilha Solteira. Os resultados demonstraram que o suabe de conjuntiva ocular foi capaz de detectar gatos infectados por esse protozoário. A coleta de amostras da conjuntiva mostrou ser um método simples, menos invasivo e pouco estressante para os gatos e seus proprietários, o que pode facilitar estudos sobre a frequência e distribuição da leishmaniose felina.

Palavras-chave: Suabe conjuntival, PCR, gatos.

\section{Introduction}

The infection by Leishmania infantum (syn. L. chagasi) (KUHLS et al., 2011) in domestic cats (Felis catus domesticus) has been reported in several European countries, Israel, and Brazil, where this zoonosis is considered endemic (POLI et al., 2002; PRATLONG et al., 2004; SAVANI et al., 2004; MAROLI et al., 2007; MARTÍN-SÁNCHEZ et al., 2007, MAIA et al., 2008). In this context, some studies of feline leishmaniasis (FL) facilitate the hypothesis that cats are susceptible to infection by Leishmania spp., like most of the canine population residing in endemic areas. However, the true level of susceptibility/ resistance of felines to the infection and its role in the leishmaniasis

*Corresponding author: Trícia Maria Ferreira de Sousa Oliveira.

Departamento de Medicina Veterinária, Faculdade de Zootecnia e Engenharia de Alimentos, Universidade de São Paulo - USP, Av. Duque de Caxias Norte,

225, Jardim Elite, CEP 13635900, Pirassununga, SP, Brasil.

e-mail: tricia@usp.br cycle is still controversial (MAIA et al., 2010). Information regarding leishmaniasis involving felines has been increasing, but there are still many questions to be answered by new studies, especially regarding the pathogenesis and the true role of the cat as a reservoir host for Leishmania spp. (AYLLON et al., 2008). The evidence that there is a transmission of feline parasites to the disease vector was proven by Maroli et al. (2007) and Silva et al. (2010), by xenodiagnosis in Italy and Brazil, respectively, thus suggesting that cats can be a secondary reservoir host for L. infantum. Such scenarios confirm the necessity of increased attention to the role of cats in the leishmaniasis urban cycle and investigation of these animals' participation as sources of disease transmission (POLI et al., 2002; SOLANO-GALLEGO et al., 2007; SHERRY et al., 2011).

This study reports the detection of Leishmania spp. DNA in conjunctival cells of cats, by PCR. 


\section{Materials and Methods}

The procedures and content of this study were approved by the Ethics Committee of the Veterinary and Animal Sciences School of the University of São Paulo (FMVZ-USP), number 2361, on August 23, 2013.

Conjunctival swabs (CS) were collected from 52 cats (male and female, young and adult) from Pirassununga-SP ( $\mathrm{n}=07)$; and from Ilha Solteira-SP $(n=45)$, in 2012, in partnership with the Pirassununga Center of Zoonosis Control (CCZ) and the Ilha Solteira Animal Protection Association (APAISA), respectively. During the collection, the clinical condition of each cat and the presence of clinical manifestations compatible with leishmaniasis were evaluated (SILVA et al., 2010).

For the harvesting of conjunctival cells, sterile swabs manufactured for use in bacteriological isolation were used. A sterile swab was rubbed on the lower conjunctiva of both eyes of each cat to collect cells. The extremities of these swabs were separated and stored in $1.5 \mathrm{~mL}$ microtubes, without DNAse and RNAse, at $4{ }^{\circ} \mathrm{C}$ until processing.

The purification of the DNA from swabs was performed using the salting-out technique (LAHIRI \& NURNBERGER, 1991), with certain modifications: instead of Triton X-100 (CAS n: 9002- 93-1, Sigma), Nonidet P-40 (CAS n: 9036-19-5, Sigma) was used, and the DNA was stored at $-20{ }^{\circ} \mathrm{C}$ until use. A first PCR reaction, previously described by Rodgers et al. (1990), in the amplification of $120 \mathrm{bp}$, for Leishmania spp. detection, were tested in triplicate. In a second reaction, also performed in triplicate, the swab samples were tested with the oligonucleotides MC1 and MC2, in the amplification of 447 bp (CORTES et al., 2004). The positive control for the reactions was a DNA sample from L. infantum (syn. L. chagasi) MCAN/BR/1984/CCC-17.481 provided by the Laboratory of Leishmaniasis of the Centro de Pesquisas em Leishmanioses, Fiocruz (Rio de Janeiro, Brazil) and the negative control was sterile, deionized water.

\section{Results and Discussion}

Fifty two cats were analyzed using conjunctival swab PCR (CSPCR), of these, 28.6\% (2/7) from the city of Pirassununga and $11.1 \%$ (5/45) from the city of Ilha Solteira - SP were positive for generic 13A and 13B primers (RODGERS et al., 1990). In total, $13.5 \%$ of the cats were positive for Leishmania spp. None of the animals was positive for the primers MC1 and MC2 (L. infantum).

Although there is a single full article about the use of ocular conjunctiva swabs to detect Leishmania in felines (CHATZIS et al., 2014), the use of conjunctival swabs in this species has had its efficacy proven in the diagnosis of several etiological agents. CSPCR has been successfully used to detect diseases such as feline herpesvirus (FHV-1), Chlamydophila felis, and Mycoplasma felis (HILLSTRÖM et al., 2012).

This method utilizing the swab to collect epithelial cell samples from the conjunctiva has been tested in canine VL detection by PCR and has been proven highly sensitive in diagnosing the disease in symptomatic (STRAUSS-AYALI et al., 2004; FERREIRA et al., 2008; PILATTI et al., 2009) and asymptomatic dogs (ALMEIDA
FERREIRA et al., 2012). Thus, non-invasive sampling is very desirable because obtaining the samples is less complex, does not require skilled labor, and facilitates the bulk collection of samples.

Furthermore, PCR has demonstrated consistent results compared with other diagnostic tests, such as microscopy and parasite culture, especially when PCR is used with samples containing a low amount of the parasite, such as blood (GARCIA et al., 2005) and conjunctival cells (ALMEIDA FERREIRA et al., 2012). This type of sample collection has particular importance in cats because they may have a low parasitic load, which can complicate the parasitological diagnosis (QUINNELL \& COURTENAY, 2009).

In all felines $(n=52)$ from which samples were collected in this study, no clinical signs that suggest leishmaniasis were observed, which corroborates the results of Chatzis et al. (2014), in which the detection CS-PCR was compared in two groups, 50 clinically normal cats and 50 with clinical signs, CS-PCR detected more cats without clinical signs (4\%). APAISA and Pirassununga's CCZ were informed about positive cats.

According to data from the Epidemiological Surveillance Center of São Paulo State (CVE-SP), from 2007 to 2014, 8 cases of human cutaneous leishmaniasis were confirmed in Pirassununga (CVE, 2014). No official data were found regarding the occurrence of VL in humans in this city. In Ilha Solteira, which is an endemic area for canine VL (ASSIS et al., 2010; QUEIROZ et al., 2010), there was one case of human cutaneous leishmaniasis and one case of human VL. In our study, none of the samples was positive for the specific primers for $L$. infantum. Such information suggests that different Leishmania spp. species circulate both in endemic and non-endemic areas of VL, thus emphasizing the importance of using PCR, because it allows identification of the species that infects the animal (relating it to the phylogenetic and phylogeographic origins) and its implication in prevention of the disease.

\section{Conclusion}

The swab collection proved to be practical, easier, and less invasive, which confirms the potential use of this type of sample collection in studies using cats. The detection of Leishmania spp. infection in cats, combined with the absence of clinical signs, might indicate that these animals are healthy carriers of these parasites.

\section{Acknowledgements}

We would like to thank FAPESP (Fundação de Amparo à Pesquisa do Estado de São Paulo), grant number 2011/00147-6.

\section{References}

Almeida Ferreira S, Leite RS, Ituassu LT, Almeida GG, Souza DM, Fujiwara RT, et al. Canine skin and conjunctival swab samples for the detection and quantification of Leishmania infantum DNA in an endemic urban area in Brazil. PLoS Negl Trop Dis 2012; 6(4): e1596. http://dx.doi. org/10.1371/journal.pntd.0001596.

Assis J, de Queiroz NM, da Silveira RC, Nunes CM, Oliveira TM, Junior AC, et al. [Comparative study of diagnostic methods for visceral 
leishmaniasis in dogs from Ilha Solteira, SP]. Rev Bras Parasitol Vet 2010; 19(1): 17-25. http://dx.doi.org/10.4322/rbpv.01901004. PMid:20385055.

Ayllon T, Tesouro MA, Amusategui I, Villaescusa A, Rodriguez-Franco F, Sainz A. Serologic and molecular evaluation of Leishmania infantum in cats from Central Spain. Ann NY Acad Sci 2008; 1149(1): 361-364. http://dx.doi.org/10.1196/annals.1428.019. PMid:19120250

Centro de Vigilância Epidemiológica "Prof. Alexandre Vranjac" - CVE. Divisão de Zoonoses. Sinan. Casos Confirmados Leishmaniose Tegumentar Am. e Leishmaniose Visc. São Paulo; 2014. Available from: http://www. cre.saude.sp.gov.br/htm/zoo/lta_dados.html.

Chatzis MK, Andreadou M, Leontides L, Kasabalis D, Mylonakis M, Koutinas AF, et al. Cytological and molecular detection of Leishmania infantum in different tissues of clinically normal and sick cats. Vet Parasitol 2014; 202(3-4): 217-225. http://dx.doi.org/10.1016/j.vetpar.2014.02.044. PMid:24629427

Cortes S, Rolão N, Ramada J, Campino L. PCR as a rapid and sensitive tool in the diagnosis of human and canine leishmaniasis using Leishmania donovani s.l.-specific kinetoplastid primers. Trans R Soc Trop Med Hyg 2004; 98(1): 12-17. http://dx.doi.org/10.1016/S0035-9203(03)000026. PMid:14702834

Ferreira SA, Ituassu LT, Melo MN, Andrade AS. Evaluation of the conjunctival swab for canine visceral leishmaniasis diagnosis by PCRhybridization in Minas Gerais State, Brazil. Vet Parasitol 2008; 152(3-4): 257-263. http://dx.doi.org/10.1016/j.vetpar.2007.12.022. PMid:18242866

Garcia AL, Kindt A, Quispe-Tintaya KW, Bermudez H, Llanos A, Arevalo J, et al. American tegumentary leishmaniasis: antigen-gene polymorphism, taxonomy and clinical pleomorphism. Infect Genet Evol 2005; 5(2): 109 116. http://dx.doi.org/10.1016/j.meegid.2004.07.003. PMid:15639742

Hillström A, Tvedten H, Källberg M, Hanås S, Lindhe A, Holst BS. Evaluation of cytologic findings in feline conjunctivitis. Vet Clin Pathol2012; 41(2): 283-290. http://dx.doi.org/10.1111/j.1939-165X.2012.00423.x. PMid:22551068

Kuhls K, Alam MZ, Cupolillo E, Ferreira GE, Mauricio IL, Oddone $\mathrm{R}$, et al. Comparative microsatellite typing of new world Leishmania infantum reveals low heterogeneity among populations and its recent old world origin. PLoS Negl Trop Dis 2011; 5(6): e1155. http://dx.doi. org/10.1371/journal.pntd.0001155. PMid:21666787

Lahiri DK, Nurnberger JI Jr. A rapid non-enzymatic method for the preparation of HMW DNA from blood for RFLP studies. Nucleic Acids Res 1991; 19(19): 5444. http://dx.doi.org/10.1093/nar/19.19.5444. PMid:1681511

Maia C, Gomes J, Cristóvão J, Nunes M, Martins A, Rebêlo E, et al. Feline Leishmania infection in a canine leishmaniasis endemic region, Portugal. Vet Parasitol 2010; 174(3-4): 336-340. http://dx.doi.org/10.1016/j. vetpar.2010.08.030. PMid:20869810

Maia C, Nunes M, Campino L. Importance of cats in zoonotic leishmaniasis in Portugal. Vector Borne Zoonotic Dis 2008; 8(4): 555-559. http://dx.doi. org/10.1089/vbz.2007.0247. PMid:18471058

Maroli M, Pennisi MG, Di Muccio T, Khoury C, Gradoni L, Gramiccia M. Infection of sandflies by a cat naturally infected with Leishmania infantum. Vet Parasitol 2007; 145(3-4): 357-360. http://dx.doi.org/10.1016/j. vetpar.2006.11.009. PMid:17174035
Martín-Sánchez J, Acedo C, Muñoz-Pérez M, Pesson B, Marchal O, MorillasMárquez F. Infection by Leishmania infantum in cats: epidemiological study in Spain. Vet Parasitol 2007; 145(3-4): 267-273. http://dx.doi. org/10.1016/j.vetpar.2006.11.005. PMid:17157440

Pilatti MM, Ferreira SA, Melo MN, Andrade AS. Comparison of PCR methods for diagnosis of canine visceral leishmaniasis in conjunctival swab samples. Res Vet Sci 2009; 87(2): 255-257. http://dx.doi.org/10.1016/j. rvsc.2009.02.005. PMid:19298988

Poli A, Abramo F, Barsotti P, Leva S, Gramiccia M, Ludovisi A, et al. Feline leishmaniosis due to Leishmania infantum in Italy. Vet Parasitol 2002; 106(3): 181-191. http://dx.doi.org/10.1016/S0304-4017(02)00081-X. PMid:12062507

Pratlong F, Rioux JA, Marty P, Faraut-Gambarelli F, Dereure J, Lanotte $\mathrm{G}$, et al. Isoenzymatic analysis of 712 strains of Leishmania infantum in the south of France and relationship of enzymatic polymorphism to clinical and epidemiological features. J Clin Microbiol 2004; 42(9): 4077-4082. http://dx.doi.org/10.1128/JCM.42.9.4077-4082.2004. PMid:15364993

Queiroz NM, de Assis J, Oliveira TM, Machado RZ, Nunes CM, Starke-Buzetti WA. [Canine visceral leishmaniasis diagnosis by immunohistochemistry and PCR in skin tissues in association with IFAT and ELISA-test]. Rev Bras Parasitol Vet 2010; 19(1): 32-38. http://dx.doi. org/10.4322/rbpv.01901006. PMid:20385057.

Quinnell RJ, Courtenay O. Transmission, reservoir hosts and control of zoonotic visceral leishmaniasis. Parasitology 2009; 136(14): 1915-1934. http://dx.doi.org/10.1017/S0031182009991156. PMid:19835643

Rodgers MR, Popper SJ, Wirth DF. Amplification of kinetoplast DNA as a tool in the detection and diagnosis of Leishmania. Exp Parasitol 1990; 71(3): 267-275. http://dx.doi.org/10.1016/0014-4894(90)90031-7. PMid:2170165

Savani ES, de Oliveira Camargo MC, de Carvalho MR, Zampieri RA, dos Santos MG, D'Auria SR, et al. The first record in the Americas of an autochthonous case of Leishmania (Leishmania) infantum chagasi in a domestic cat (Felix catus) from Cotia County, São Paulo State, Brazil. Vet Parasitol 2004; 120(3): 229-233. http://dx.doi.org/10.1016/j. vetpar.2004.01.008. PMid:15041097

Sherry K, Miró G, Trotta M, Miranda C, Montoya A, Espinosa C, et al. A serological and molecular study of Leishmania infantum infection in cats from the Island of Ibiza (Spain). Vector Borne Zoonotic Dis 2011; 11(3): 239-245. http://dx.doi.org/10.1089/vbz.2009.0251. PMid:20804432

Silva SM, Rabelo PF, Gontijo NF, Ribeiro RR, Melo MN, Ribeiro VM, et al. First report of infection of Lutzomyia longipalpis by Leishmania (Leishmania) infantum from a naturally infected cat of Brazil. Vet Parasitol 2010; 174(1-2): 150-154. http://dx.doi.org/10.1016/j.vetpar.2010.08.005. PMid:20832944

Solano-Gallego L, Rodríguez-Cortés A, Iniesta L, Quintana J, Pastor J, Espada Y, et al. Cross-sectional serosurvey of feline leishmaniasis in ecoregions around the Northwestern Mediterranean. Am J Trop Med Hyg 2007; 76(4): 676-680. PMid:17426169.

Strauss-Ayali D, Jaffe CL, Burshtain O, Gonen L, Baneth G. Polymerase chain reaction using noninvasively obtained samples, for the detection of Leishmania infantum DNA in dogs. J Infect Dis 2004; 189(9): 17291733. http://dx.doi.org/10.1086/383281. PMid:15116312 